\title{
Influence of Mulching Material on Growth and Yield of Strawberry under Polyhouse Condition
}

\author{
Haobam Neljosh Meetei $^{1 *}$, R. K. Dilip Singh ${ }^{1}$ and Basu Langpoklakpam² \\ ${ }^{1}$ College of Agriculture, ${ }^{2}$ KVK, South Garo Hill, Central Agricultural University, Imphal, \\ Manipur, India \\ *Corresponding author
}

\section{A B S T R A C T}

\begin{tabular}{l} 
Key w o r d s \\
Mulching, Sweet \\
Charlie, Chandler, \\
Parameters, \\
Cultivar \\
\hline Article Info \\
\hline $\begin{array}{l}\text { Accepted: } \\
\text { 12 December } 2020 \\
\text { Available Online: } \\
\text { 10 January 2021 }\end{array}$ \\
\hline
\end{tabular}

The present experiment were carried out at the research field of Horticultural Research Farm, Andro, Central Agricultural University, Imphal, which is $27 \mathrm{~km}$ from CAU during Oct,2018-19,Mar. The experimental site is located at latitude of $24^{\circ} 45.89^{\prime} \mathrm{N}$ and longitude of $94^{\circ} 03.46^{\prime} \mathrm{S}$, at an altitude of $880 \mathrm{~m}$ above mean sea level. The experiment was conducted to chalked out the best mulching and variety and their combined effect on plant growth and yield. Mulching consist of Straw mulch (M2), Black polyethylene (M1), Saw dust (M3) and cultivars Sweet Charlie (V1) and Chandler (V1). The total treatment consist of 8. It was two factorial experiment comprising 8 treatment combinations with three replications. Hence the design of the experiment was Factorial Randomized Block Design and total number of seedlings used were 480 with 20 seedlings per treatment per replication. From the data recorded after analysed, it was noticed that the parameters showed significant variations because of effect of two factors. With regard to mulching applied, highest plant height $(21.84 \mathrm{~cm})$, Crown $\operatorname{spread}(29.85 \mathrm{~cm})$, number of leaves per plant $(17.07)$, leaf area $\left(77.38 \mathrm{~cm}^{2}\right)$, single fruit weight $(9.84 \mathrm{~g})$ and yield $(2.51 \mathrm{t} / \mathrm{ha})$ were observed in Straw mulch. As for cultivar is concerned Chandler (V2) reported maximum in the parameters mentioned plant height $(20.20 \mathrm{~cm})$, crown spread $(28.08 \mathrm{~cm})$, number of leaves per plant $(15.90)$, leaf area $\left(73.45 \mathrm{~cm}^{2}\right)$, single fruit weight $(8.06 \mathrm{~g})$, yield $(1.84 \mathrm{t} / \mathrm{ha})$ and Sweet Charlie (V1) observed minimum value. For the combined influence of two factors mentioned earlier Straw Mulch (M2) with Chandler (V2) i.e M2V2 observed maximum in the given parameters while M0V1 (Control x Sweet Charlie) observed minimum value. Therefore it can be inferred that Straw mulch (M2) when mulch in Chandler (V2) gave better result for the growth and yield parameters.

\section{Introduction}

Strawberry (Fragaria $\mathrm{x}$ ananassa Dutch.) is one of the most important temperate fruit which can also be grown in tropical and subtropical climate with some efforts. It is a herbaceous perennial crop belonging to family Rosaseae. It is a small fruit crop of great nutritional and medicinal value (Maas et al., 1991). Scientifically, strawberry is said to be an aggregate fruit as it is derived from the receptacles rather than plant ovary. 
Various berry fruits along with low growing Rubuspseudo-japonica and Japanese strawberry species were introduced in the middle of the $10^{\text {th }}$ and $18^{\text {th }}$ centuries in the ancient world "ichibigo" in Japan (Oda and Nishimura, 2009). In India, strawberry is grown in Himachal Pradesh, Maharashtra, West Bengal, Delhi, Haryana, Punjab and Rajasthan in an area of one million hectare with a production of 8 million tonnes (Anonymous, 2015-16). In India, strawberry is usually planted in second fortnight of October with traditional methods which restrict the fruit availability for a short period of (one and half month). However, there are several reports available in the literature indicating that strawberry can be planted at different times of the year depending on the variety, location and climate (Sharma and Sharma, 2004). Among different production practices of strawberry, mulching is considered as the most important cultural practice as it plays an essential role in soil moisture conservation, weed control, regulation of soil hydrothermal regime, besides keeping the delicate fruit neat and clean as strawberry is a low growing perennial herb (Abbott and Gough, 1992; Gupta and Acharya, 1993 and Tarara, 2000).

Investigations on impact of different mulching materials on fruit quality has indicated that strawberry is very responsive to the different mulching materials and climatic conditions (Wang et al., 1998; Raina et al., 2004 and Shylla and Sharma, 2010).

Cultivation of strawberry in NE-region with special reference to Manipur in commercial scale is very rare as compare to non traditional cultivated area of India. Therefore, taking all points under considerations, the present study is designed to study the Influence of Mulching material on the growth and yield of strawberry under poly-house condition with the following objectives include to find out the best mulching material. Then to find out the better cultivar and also to find out the best treatment combination.

\section{Materials and Methods}

An experiment was conducted at the Horticultural Research Farm, Andro, College of Agriculture, Central Agricultural University, Imphal during the year Oct,20182019March, to evaluate the influence of mulching material on growth and yield of strawberry under polyhouse condition. The experiment was laid out in Factorial Randomized Block Design with eight treatment combination in three replications. The mulch used were Straw (M2), Black polyethylene (M1), Saw dust (M3) and Control (unmulch) (M0) while the cultivars were Sweet Charlie (V1) and Chandler (V2).

The growth and yield parameters recorded during the experiment were Plant height $(\mathrm{cm})$, Crown Spread $(\mathrm{cm})$, Leaf area $\left(\mathrm{cm}^{2}\right)$, Number of leaves per plant, Single fruit weight $(\mathrm{g})$, Yield (t/ha).

The Plant height were recorded in centimetre from the soil level to the tip of the plant. The plant spread was measured in two directions (NS and EW) at right angles to each other and average were work out. Leaf area were measured using leaf area meter 211. Numbers of leaves per plant were counted for each treatment. Weight of single fruit was measured for each treatment after harvest. The total fruit yield for each treatment was estimated in terms of $\mathrm{t} / \mathrm{ha}$.

\section{Results and Discussion}

Influence of mulching material and variety on growth and yield were found to be significantly differed. The relevant data and discussions have been presented below: 
Influence of mulching and variety on growth and yield of strawberry

Result presented in Table 1 and 2, exhibited that mulching and varietal treatment increased the plant height, crown spread, leaf area, single fruit weight and yield. Among the mulching Straw Mulch recorded the maximum plant height $(21.84 \mathrm{~cm})$, Crown Spread $(29.85 \mathrm{~cm})$, Leaf area $\left(77.38 \mathrm{~cm}^{2}\right)$, single fruit weight $(9.84 \mathrm{~g})$ and yield (2.51t/ha). Black polyethylene mulch observed the value on par with the Straw Mulch of the above parameters while minimum value were reported in Control.
The maximum value observed in straw mulch may be attributed to the better aeration around plant rhizosphere creating favourable atmosphere for nutrient uptake and translocating it to other parts of plant for synthesis of food material which then supplied to the fruit regularly during fruit development stage and also the plant vigour might also have contributed ultimately in the yield. Also straw conserved moisture which help in continuous supply of water and straw upon decomposition added nutrient to the soil. These above findings were in conformity with the earlier work of Misra (1996), S. Sujatha et al., (2018), Ali and Gaur (2013) and Das et al., (2010), Moor et al., (2004).

Table.1 Influence of mulching and variety on growth of strawberry

\begin{tabular}{|l|l|l|l|l|}
\hline \multicolumn{1}{|c|}{ Treatment } & $\begin{array}{l}\text { Plant } \\
\text { height }\end{array}$ & $\begin{array}{l}\text { Crown } \\
\text { spread } \\
\text { (cm) }\end{array}$ & $\begin{array}{l}\text { Number of } \\
\text { leaves per } \\
\text { plant }\end{array}$ & $\begin{array}{l}\text { Leaf } \\
\text { area } \\
\text { (cm }^{2}\end{array}$ \\
\hline Mulching Material & & & & \\
\hline M0 & 16.53 & 24.72 & 13.32 & 66.30 \\
\hline M1 & 21.34 & 28.17 & 16.04 & 73.40 \\
\hline M2 & 21.84 & 29.85 & 17.07 & 77.38 \\
\hline M3 & 17.84 & 26.23 & 15.08 & 68.66 \\
\hline SE(d) \pm & 0.36 & 0.42 & 0.23 & 0.96 \\
\hline CD(0.05) & 0.77 & 0.89 & 0.48 & 2.06 \\
\hline & & & & \\
\hline Variety & & & & \\
\hline V1 & 18.58 & 26.40 & 14.85 & 69.42 \\
\hline V2 & 20.20 & 28.08 & 15.90 & 73.45 \\
\hline SE(d) \pm & 0.25 & 0.29 & 0.16 & 0.68 \\
\hline CD(0.05) & 0.54 & 0.63 & 0.34 & 1.46 \\
\hline & & & & \\
\hline Mulching material and variety interaction (MxV) & & & & \\
\hline M0V1 & 15.97 & 23.47 & 13.05 & 65.88 \\
\hline M0V2 & 17.09 & 25.97 & 13.58 & 66.72 \\
\hline M1V1 & 20.19 & 28.01 & 15.49 & 70.46 \\
\hline M1V2 & 22.49 & 28.32 & 16.59 & 76.34 \\
\hline M2V1 & 20.90 & 28.15 & 15.99 & 73.54 \\
\hline M2V2 & 22.78 & 31.54 & 18.15 & 81.22 \\
\hline M3V1 & 17.24 & 25.98 & 14.87 & 67.81 \\
\hline M3V2 & 18.44 & 26.47 & 15.29 & 69.51 \\
\hline SE(d) \pm & 0.51 & 0.59 & 0.32 & 1.36 \\
\hline CD(0.05) & 1.08 & 1.26 & 0.69 & 2.91 \\
\hline
\end{tabular}


Table.2 Influence of mulching and variety on yield of strawberry

\begin{tabular}{|l|c|c|}
\hline \multicolumn{1}{|c|}{ Treatment } & $\begin{array}{c}\text { Single fruit } \\
\text { weight } \mathbf{( g )}\end{array}$ & $\begin{array}{c}\text { Yield } \\
\text { (t/ha) }\end{array}$ \\
\hline Mulching Material & 4.61 & 1.00 \\
\hline M0 & 8.70 & 1.74 \\
\hline M1 & 9.84 & 2.51 \\
\hline M2 & 6.17 & 1.19 \\
\hline M3 & 0.11 & 0.03 \\
\hline SE(d) & 0.24 & 0.07 \\
\hline CD(0.05) & & \\
\hline & & \\
\hline Variety & 6.73 & 1.37 \\
\hline V1 & 8.06 & 1.84 \\
\hline V2 & 0.08 & 0.02 \\
\hline SE(d) \pm & 0.17 & 0.05 \\
\hline CD(0.05) & & \\
\hline & & \\
\hline Mulching material and variety interaction (MxV) & 4.61 & 0.86 \\
\hline M0V1 & 5.11 & 1.14 \\
\hline M0V2 & 7.50 & 1.28 \\
\hline M1V1 & 9.90 & 2.19 \\
\hline M1V2 & 8.70 & 2.18 \\
\hline M2V1 & 10.98 & 2.83 \\
\hline M2V2 & 6.10 & 1.16 \\
\hline M3V1 & 6.23 & 1.21 \\
\hline M3V2 & 0.16 & 0.05 \\
\hline SE(d) \pm & 0.34 & 0.10 \\
\hline CD(0.05)
\end{tabular}

As reported for cultivars, Chandler noticed the maximum Plant height $(20.20 \mathrm{~cm})$, Crown Spread $(28.08 \mathrm{~cm})$, Leaf area $\left(73.45 \mathrm{~cm}^{2}\right)$, number of leaves per plant (15.90), single fruit weight (8.06g) and yield (1.84t/ha). Sweet Charlie reported the minimum value. The higher value reported in cultivar Chandler may be due to the varietal genetic background which may also have been favoured by the microclimate during their growth period which in turn translate into yield. The present findings were found to be similar with the previous findings of Umesh Kumar et al., (2020), Amarjeet Kaur et al., (2017), A. Kumar and I. Ahad (2012).

For treatment combination M2V2 (Straw Mulch x Chandler) were reported higher in growth aspect viz. Plant height $(22.78 \mathrm{~cm})$, Crown spread $(31.54 \mathrm{~cm})$, number of leaves per plant(18.15), leaf area $\left(81.22 \mathrm{~cm}^{2}\right)$, single fruit weight $(10.98 \mathrm{~g})$ and yield(2.83t/ha).

From the above mentioned explanation and data, it can be summarised and conclude that Straw mulch were found to be beneficial as compared to other mulch taken in terms of plant height $(\mathrm{cm})$, crown spread $(\mathrm{cm})$, number of leaves per plant, leaf area $\left(\mathrm{cm}^{2}\right)$, single fruit weight (g) and yield ( $\mathrm{t} / \mathrm{ha}$ ) where as Chandler (V2) reported maximum value of the above parameters than Sweet Charlie (V1).

The treatment combination M2V2 (Straw Mulch $\mathrm{x}$ Chandler) were found to be 
maximum in all the parameters plant height $(22.78 \mathrm{~cm})$, crown spread $(31.54 \mathrm{~cm})$, number of leaves per plant (18.15), leaf area $\left(81.22 \mathrm{~cm}^{2}\right)$, single fruit weight $(10.98 \mathrm{~g})$ and yield (2.83t/ha) and M0V1 (Control x Sweet Charlie) were found to be minimum in all these parameters.

Thus it can be inferred from this work that, for this area it was observed that straw mulch were found to impart beneficial effect in terms of growth and yield from the rest of the mulch used and for cv. Chandler (V2) performed better than Sweet Charlie (V1) in terms of growth and yield. For treatment combination M2V2 were better than other treatment combination and M0V1 were found minimum in terms of growth and yield.

\section{Acknowledgement}

The authors are grateful for the mental and necessary guidance and financial support provided during the research work to the College of Agriculture, Central Agriculture University, Imphal.

\section{References}

Abbott, J.D. and Gough, R.E.(1992). Comparision of winter mulches of several strawberry cultivars. Journal of Small Fruit and Viticulture., 6(1): 5158.

Ali, A. and Gaur, G.S. (20130. Effect of organic mulches on runner production of strawberry (Fragaria $\times$ ananassa Duch.). Asian Journal of Bio. Science. 8 (2): $175-179$.

Anonymous (2015 - 2016). Indian Horticulture Database -NHB, Ministry of Agriculture, Govt of India.

Das, B.C., Maji, S. and Mulieh, S.R. (2010). Response of soil covers on guava cv. L49. Journal of. Crops \& Weeds, 6 (2): $10-14$.
Kaur, Amarjeet., Singh, Rajandeep and Singh, Harmeet., (2017). Evaluation of Strawberry Cultivars For Growth and Yield Characteristics in Sub Tropical Region of Punjab. International Journal of. Advance. Research. 5(3), 257-264

Kumar, A. and Ahad, I. (2012). Growth, yield and fruit quality of strawberry under protected cultivation in South Kashmir. Advances in Horticultural Science(Adv. Hort. Sci.,), 26(2): 88-91.

Kumar, Umesh, Sonkar, Priyamvada and Dhakad, Angurbala.( 2020). Study on strawberry (Fragaria $\mathrm{x}$ ananassa Dutch.) varieties for growth, fruit bio-chemical and yield parameters under western malwa plateau conditions of Madhya Pradesh. Journal of Pharmacognosy and Phytochemistry. 9(2): 1070-1073.

Gupta, R. and Acharya, C.L. (1992). Effect of mulch induced hydrothermal regime on root growth, water use efficiency, yield and quality of strawberry. Journal of Indian Societyof Soil Science., 41: 1725.

Maas, J.L., S.Y. Wang and G.J. Galletta. (1991). Evaluation of Strawberry cultivars for ellagic acid content. Horticultural Science., 26: 66-68.

Misra, O.R. (1996). Influence of mulching material and antitranspirants on water consumption yield and yield contributing characters of different rain fed wheat varieties. Crop Research (Hisar) 11(1): 1-8. [Wheat, Barley and Triticale Abst. 1996, 13(5): 490].

Moor, U, Karp, K. and Poldama, P. (2004). Effect of mulching and fertigation on quality of strawberries. Agricultural and Food Science. 13: 256-267.

Oda, Y and Nishimura, K. (2009). "Ichibigo" - Japanese name of strawberry- its origin and historical change of phonogram for strawberry in Japan. Acta Horticulturae, 842: 611-618.

Sujatha, S., Suchitra, V., Swami, D.V., 
Subbaramamma, P., Uma Krishna, K. and Saravanan, L. (2018).Influence of mulching materials on growth and yield of strawberry (Fragaria ananassa duch.) cv. CAMAROSA under shadenet conditions of coastal Andhra Pradesh.International Journal of agricultural. Science, 14 (1): 219-224.

Sharma, V.P. and Sharma, R.R. (2004). The strawberry. ICAR, New Delhi, India, pp 166.

Raina, J.N., Thakur, B.C. and Sephia, R. (2004). Effect of mulches on soil hydrothermal regimes, root growth, yield and quality of strawberry. Annals of Plant and Soil Research., 12:
6-30.

Shylla, B. and Sharma, C.L. (2010). Evaluation of mulch colour for enhancing winter strawberry production under polyhouse in mid hills of Himachal Pradesh. Journal of Horticultural Science., 33: 636-640.

Tarara, J.M. (2000). Microclimate modification with plastic mulch. Horticultural Science., 35: 169-319.

Wang, S., Galletta, G. and Camp, M.(1998). Mulch types affect fruit quality and composition of two strawberry genotypes. Horticultural Science., 33: 636-640.

\section{How to cite this article:}

Haobam Neljosh Meetei, R. K. Dilip Singh and Basu Langpoklakpam. 2021. Influence of Mulching Material on Growth and Yield of Strawberry under Polyhouse Condition. Int.J.Curr.Microbiol.App.Sci. 10(01): 1656-1661. doi: https://doi.org/10.20546/ijcmas.2021.1001.193 